\title{
TRAJETÓRIA PESSOAL NO CAMPO DA PESQUISA HISTÓRICA ${ }^{1}$
}

\section{Maria Luisa Santos Ribeiro}

Na condição de professora de uma universidade católica, como a PUCSP, e de uma profissional com uma posição claramente favorável à escola pública, gratuita, obrigatória em seus graus iniciais e laica, vi-me diretamente envolvida no movimento de professores universitários em razão das crises pelas quais passou o ensino nos anos 70 e 80 e, particularmente, envolvida no movimento dos professores da PUCSP, em conseqüência dos reflexos dessa crise no interior dessa universidade com as especificidades que comportava.

Desse modo, como participante de uma fração de professores, alunos e funcionários que compartilhavam alguns princípios e, em conseqüência, tomavam uma determinada posição político-ideológica diante da situação da época em questão, fui levada, assim como boa parte dos envolvidos, a estudos e discussões que foram produzindo uma elaboração teórica que chegou a ser registrada por alguns de nós.

Isso permitiu-me entender ainda mais objetivamente a posição da Igreja Católica no campo da educação escolar no contexto da sociedade brasileira.

Desse entendimento resultaram escritos parciais que, divulgados no interior da categoria durante os acontecimentos, puderam ser contestados e testados de imediato. Resultou também num trabalho escrito de maior porte, ainda não publicado, que tem por título "A luta pelo ensino público e gratuito numa universidade particular - a PUCSP".

Considerei que essa luta apresenta fases bastantes distintas que precisam ser minimamente demarcadas e consideradas no que tenham de geral e de particular.

A primeira fase, que marca propriamente os anos 70, e pode-se considerar que teve início em 1968, termina em 1982. A decretação do Ato Institucional no 5 de início e a vitória eleitoral de candidatos de oposição ao governo militar a alguns dos governos estaduais, dentre os quais o de São Paulo, no final, são os acontecimentos sócio-políticos gerais que, a meu ver, delimitam essa fase por determinarem um conteúdo específico à referida luta.

Do ponto de vista político mais geral, é um período marcado pela ditadura militar e pela busca de rearticulação da luta contra ela. Do ponto de vista econômico é a época do "Milagre Brasileiro"(1968/1973) e de sua crise, a partir de 1974.

\footnotetext{
${ }^{1}$ Depoimento Prestado no IV Seminário Nacional do Grupo HISTEDBR - Trajetória Pessoal no Campo da Pesquisa Histórica.
} 
Em relação à política educacional, no que diz respeito aos recursos, quer seja no período do "Milagre" ou de sua crise, é um momento de cortes drásticos tanto e mais fortemente para a rede escolar pública como para as escolas particulares parcialmente subsidiadas com recursos públicos, como era o caso da PUCSP.

Em conseqüência, o eixo da luta pelo ensino público e gratuito numa escola particular como a PUCSP se define através da luta contra a ditadura militar. A certeza de que os parcos recursos destinados à educação escolar "dos civis" tornavam quase impossível aos governos militares colocar em prática uma agressiva política de subsídios das escolas particulares, fez com que a luta contra este aspecto da política pró-privatização do governo não se constituísse no conteúdo específico da luta pelo ensino público e gratuito durante a fase relativa aos anos 70. Assim sendo, dela puderam fazer parte também os professores, alunos e funcionários sob influência teórica da "Teologia da Libertação", a chamada ala progressista da Igreja Católica.

A reconquista de parte das liberdades democráticas, bem como a possibilidade da existência de recursos, tanto em nível estadual como federal, marca uma segunda fase da luta que, tendo início em 1982 se completa em 1987, quando a Igreja Católica, por intermédio do Grão Chanceler da PUCSP, D. Paulo Evaristo Arns, torna público o seu reestreitamento com os compromissos elitistas da universidade, em sua luta para continuar existindo enquanto universidade particular católica.

A possibilidade da existência de recursos dá ensejo, de um lado, a que todos os grupos mais ligados à Igreja Católica intensifiquem sua busca de subsídios através dos antigos mecanismos e também da criação de mecanismos novos. De outro lado, determina que o eixo central da luta pelo ensino público e gratuito numa escola particular como a PUCSP passe a ser o empenho no sentido de obter por via legal garantias de recursos públicos para as escolas públicas. Obviamente, nessa fase rompe-se a aliança com a chamada ala progressista da Igreja Católica.

Daí por diante tem início uma terceira fase da luta que, não só pelo fato de estar num período inicial (quando termina a investigação feita por mim em setembro de 1991), mas também e fundamentalmente por conter elementos da primeira fase combinados com elementos da segunda, vinha se revelando muito difícil, levando o movimento a colocar-se mais propriamente numa posição defensiva. Suponho que ela tenha durado até 1992, quando em novembro toma posse como reitor o Prof. Dr. Joel Martins. 
Entendia que nessa fase estavam presentes elementos das fases anteriores, por aceitar que os interesses privados impostos pelos monopólios internacionais à sociedade brasileira como um todo colocavam outra vez em risco as liberdades democráticas e o pouco que restava de conquistas em termos de um patrimônio propriamente público no que se refere à rede de ensino.

Em relação a uma instituição como a PUCSP, tais tendências fortalecem internamente os grupos conservadores e reacionários, alguns dos quais travestidos de modernidade; grupos esses cujos representantes passam a fazer parte da direção acadêmica e administrativa da universidade. No entanto, é um fortalecimento relativo e duplamente negativo para a PUCSP, porque as divergências secundárias entre esses vários grupos acabam por gerar constantes atritos e rompimentos de alianças. A conseqüente instabilidade resultante acaba por tornar impossível qualquer tentativa de resposta mais consistente e sistemática aos graves problemas existentes no interior da instituição.

É uma fase que para ser compreendida exige, a meu ver, que se tome como tema de reflexão essa "nova" ofensiva pró-privalização. Entendia que sem um bom grau de domínio dos fundamentos de uma política dessa natureza não era possível traçar uma adequada e necessária direção para o movimento de professores vinculado à luta pelo ensino público e gratuito.

Assim entendendo, foi com essa reflexão que dei início à síntese interpretativa, de tal modo que a terceira fase constitui o primeiro capítulo do trabalho apresentado por escrito.

Considero ser esse um resultado de pesquisa histórica determinada muito diretamente pela necessidade de participação efetiva num movimento, contando com o maior grau de orientação teórica possível.

Peço licença ao autor da frase de que "nada mais conservador que um liberal no poder" para parafraseá-lo, já que, com essa participação efetiva articulada a esse trabalho teórico, pude compreender e convencer-me de que, em se tratando de educação escolar, nada mais conservador do que a ala chamada "progressista" da Igreja Católica, quando na Reitoria de uma universidade ou mesmo quando numa secretaria pública de educação.

Concluindo estas reflexões motivadas pelo tema da trajetória pessoal no campo da pesquisa histórica em educação, reforço a idéia de que a minha trajetória é determinada diretamente por exigência do exercício do magistério em sala de aula, da carreira acadêmica e do exercício do magistério na condição de membro de uma categoria em movimento, 
buscando fôlego teórico numa concepção que exige uma grau sempre crescente de coerência teórico-prática. O que não é nada fácil!!! 